\title{
sciendo
}

\section{AGE AND GROWTH OF BLACK-BELLIED ANGLERFISH Lophius budegassa (Spinola, 1807) FROM THE CENTRAL AEGEAN SEA, TURKEY}

\author{
Ahmet Mert Şenbahar*, Okan Özaydin
}

Ege University, Faculty of Fisheries, Department of Marine-Inland Waters Sciences and Technology, 35100, Bornova, Izmir, Turkey

*Corresponding Author, Email: a.mertsenbahar@gmail.com

\section{ARTICLE INFO}

Received: 15 August 2019

Accepted: 14 January 2020

\section{Keywords:}

Angler fish

Lophius budegassa

Age

Growth

Central Aegean Sea

\begin{abstract}
A total of 558 specimens of black-bellied anglerfish Lophius budegassa (Spinola, 1807) were collected by the vessels engaged in commercial trawl fishing in the Central Aegean Sea between September 2017 and August 2018 in order to determine age and growth. Ageing was based on growth ring counts of transverse sections of the illicium (first ray of the dorsal fin). By reading the illicium, individuals were found within II-XI age groups. Total lengths and weights ranged between $12.0-65.0 \mathrm{~cm}$ and $24.5-4682.0 \mathrm{~g}$, respectively. Von Bertalanffy growth parameters were estimated for males, females and combined sexes of $L$. budegassa. The results are compared with previous studies.
\end{abstract}

How to Cite

Şenbahar, A.M., Özaydin, O. (2020): Age and growth of black-bellied anglerfish Lophius budegassa (spinola, 1807) from the central Aegean sea, Turkey. Croatian Journal of Fisheries, 78, 45-51. DOI: 10.2478/cjf-20200005.

\section{INTRODUCTION}

The family Lophiidae is represented by 28 species of 4 genera across the world (Fishbase, 2018). In the Mediterranean basin, the genus of Lophius is represented by two species: Lophius piscatorius and Lophius budegassa. Most of these species are present in shallow and deeper waters. They feed on benthic species, fish and crustaceans because they are carnivorous (Whitehead et al., 1986). They attract prey by means of their fishing filament (Maigret and Ly, 1986). Black and white anglerfish are typical shallow-living species, the former having a depth range between $70 \mathrm{~m}$ and $800 \mathrm{~m}$, and the latter extending to depths $>1000 \mathrm{~m}$ (Dardignac, 1988). Black anglerfish has a more southern distribution, the Mediterranean and Eastern North Atlantic from the British Isles to Senegal (Fishbase, 2018). Anglerfish age estimation is generally a difficult task to complete. The ageing technique based on illicia (first ray of the dorsal fin) has been standardized for the both anglerfish species from the European North Atlantic, as a result of four ageing workshops (Anon, 1991, 1997, 1999; Landa et al., 2002; Garcia-Rodriguez et al., 2005). 


\section{MATERIALS AND METHODS}

The study materials were obtained from the monthly bottom trawls between September 2017 and August 2018 from the Central Aegean Sea (Fig. 1). Biological samplings were carried out on each of the individuals from the catch by measuring their total length in $\mathrm{mm}$ and total weight in $\mathrm{gr}$ with precision. After these measurements, the species were dissected for determining the sex and sexual maturity by macroscopic observation, after which the illicia of individuals were taken and cut.

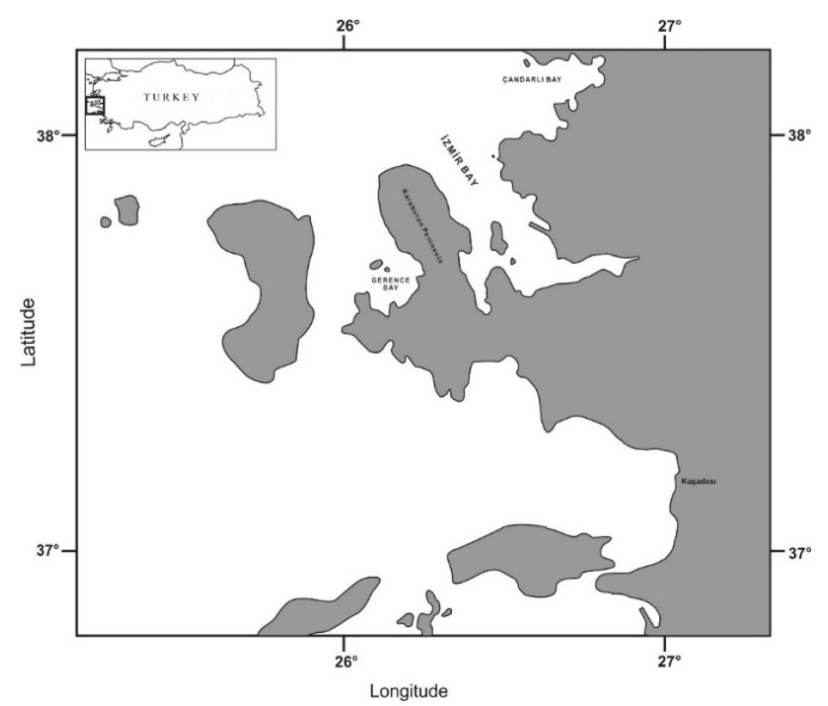

Fig 1. Sampling area of Lophius budegassa

\section{Biometric relationships}

In determining the functional relationship between the length and weight of the samples, equation $W=a L^{b}$ was used, where $(W)$ is the weight in grams, $(L)$ is the length in centimeters, $(a)$ and $(b)$ are the parameters to be estimated, with $(b)$ being the coefficient of allometry. In addition, a significance test (Sokal and Rohlf, 1969) was carried out to determine if the $(b)$ coefficient was different from " 3 " and the level of significance was determined with a Student $t$-test.

The length-weight relationship was calculated separately for female, male and all individuals.

Growth equations developed by Von Bertalanffy were used in numerical study of growth (Sparre et al., 1989).

For age-length relationship: $L_{t}=L_{\infty}\left[1-e^{-k(t-t)}\right]$, where $\left(L_{\infty}\right)$ is the maximum asymptotic length and weight, $\left(L_{t}\right)$ is the mean length and weight of fish in " $t$ " age, $(k)$ is the Brody growth coefficient (year $\left.{ }^{-1}\right),(t)$ is age of fish (years), $\left(t_{0}\right)$ : the theoretical age of fish before hatching (year), (e): define the logarithmic base.

\section{Age estimation and illicia reading}

Illicium was used for age determination of all individuals, and in order to facilitate the cutting process the base of illicium was cut from the lifted apical end. After cutting each angler fishes, the illicium samples were stored in an envelope where the data of the sample was recorded. For the determination of age, the following procedures were performed in order to take a cross section with a thickness of $0.5 \mathrm{~mm}$ using a microscope (Duarte et al., 2002). Procedures consisted of moulding, slicing and bounding. Age reading was performed by three different readers using a microscope (100x) under transmitted light and also by a photographing method.

\section{RESULTS}

During the research, a total of 558 individuals were obtained; $48.9 \%(n=273)$ were male, $46.8 \%(n=261)$ were female and $4.3 \%(n=24)$ were undefined. The female: male ratio was calculated as 0.95: 1 . As a result of the $\chi 2$ analysis, it was found that there was no statistical difference between the male and female ratios of the samples collected all year round $\left(\chi 2=0.268<\chi 2 \mathrm{t}_{0.005}=1.65\right.$, $p<0.05)$. Sizes varied from $12 \mathrm{~cm}$ to $65 \mathrm{~cm}$ in total length. It was determined that male individuals were between 12.2 - $43 \mathrm{~cm}$, female individuals were between $12-65 \mathrm{~cm}$ and all individuals were between $12-65 \mathrm{~cm}$ minimum and maximum total length values (Table 1).

In the calculation of total length distribution frequencies of the individuals, it was observed that most of the female individuals were between 15.0 - $20.0 \mathrm{~cm}$ (21\%), male individuals were in the range of $14.0-30.0 \mathrm{~cm} \mathrm{(19 \% )} \mathrm{and}$ all individuals were found to be dominant in the 15.0-20.0 $\mathrm{cm}(18 \%)$ length groups. Table 2 shows the results that were obtained for the estimations of the parameters of the length-weight relationship (LWR) result from the data belonging to different groups: males, females and total.

The values of the allometry coefficient were significantly different from " 3 " in all cases. Length-weight relationship of total, male and female individuals was found to be $W$ $=0,0165 L^{2,9478}\left(r^{2}=0.93 ; N=558\right), W=0,0289 L^{2,7576}\left(r^{2}=\right.$ $0.90 ; N=273)$ and $W=0,0135 L^{3,0227}\left(r^{2}=0.94 ; N=261\right)$, respectively. Due to LWR data parameters for female, male and total individuals, there was a significant difference in allometric growth between male and female individuals (t-test, $t=60.9>\mathrm{t}_{0.05,543}=1.65$ ). Accordingly, female and total individuals showed positive allometric growth, whereas male individuals showed a negative allometric growth (t-test, $t=4.35 ; 2,32>\mathrm{t}_{0.05272 ; 534}=1.65$ ).

The $L_{\infty}$ was estimated for both sexes and according to Von Bertalanffy growth model, growth values of males were found to be $L_{\infty}=68.50 \mathrm{~cm}, k=0.223$ per year, $t_{0}=-0.171$, for the females $L_{\infty}=73.52 \mathrm{~cm}, k=0.186$ per year, $t_{0}=-0.158$ and for the combined sexes $L_{\infty}=74.83 \mathrm{~cm}, k=0.18$ per year, $t_{0}=-0.34$ and $\varphi=2.99$. According to calculated results of VBGF by sexes, differentiation starts from age 5 (Fig. 2). 
Table 1. Total length ( $\mathrm{TL})$ values of individuals in seasons

\begin{tabular}{|c|c|c|c|c|c|c|c|c|c|c|c|c|}
\hline & \multicolumn{3}{|c|}{$n$} & \multicolumn{3}{|c|}{ Min. TL (cm) } & \multicolumn{3}{|c|}{ Max. TL (cm) } & \multicolumn{3}{|c|}{ Mean TL $(\mathrm{cm}) \pm \mathrm{SE}$} \\
\hline & $\hat{\sigma}$ & $q$ & ๙0+ & $\widehat{0}$ & 9 & 10+ & $\widehat{0}$ & 9 & 10+ & $\widehat{o}$ & 9 & 10+ \\
\hline Spring & 28 & 36 & 65 & 14.3 & 15.6 & 14.3 & 35.4 & 50.2 & 50.2 & $20.1 \pm 0.74$ & $28.5 \pm 1.96$ & $23.4 \pm 0.08$ \\
\hline Summer & 6 & 8 & 13 & 23.5 & 20.3 & 20.3 & 43 & 65 & 65.0 & $31.8 \pm 2.35$ & $40.4 \pm 4.67$ & $37.5 \pm 3.33$ \\
\hline Fall & 135 & 118 & 275 & 12.2 & 12 & 12.0 & 42.4 & 62 & 62.0 & $21.6 \pm 0.43$ & $23.7 \pm 0.90$ & $22.0 \pm 0.46$ \\
\hline Winter & 104 & 99 & 205 & 14.5 & 15.1 & 14.5 & 37.8 & 38.4 & 38.4 & $21.8 \pm 0.52$ & $22.9 \pm 0.61$ & $22.3 \pm 0.40$ \\
\hline Total & 273 & 261 & 558 & 12.2 & 12 & 12.0 & 43 & 65 & 65.0 & $21.8 \pm 0.32$ & $24.2 \pm 0.32$ & $22.6 \pm 0.31$ \\
\hline
\end{tabular}

Table 2. Total length-weight relationship values of female, male and total individuals

\begin{tabular}{lcccccc}
\hline \hline & $\mathbf{n}$ & $\mathbf{a}$ & $\mathbf{b}$ & se(b) & $\mathbf{r}^{\mathbf{2}}$ & t-test \\
\hline Males & 273 & 0,0289 & 2,7576 & 0,0556 & 0,9007 & 4,35 \\
Females & 261 & 0,0135 & 3,0227 & 0,0437 & 0,9479 & 0,51 \\
Total & 558 & 0,0165 & 2,9478 & 0,0332 & 0,9394 & 1,57 \\
\hline
\end{tabular}

$\left(t\right.$-test, $\left.\mathrm{t}<\mathrm{t}_{0.05, \mathrm{n}>200}=1.65\right)$

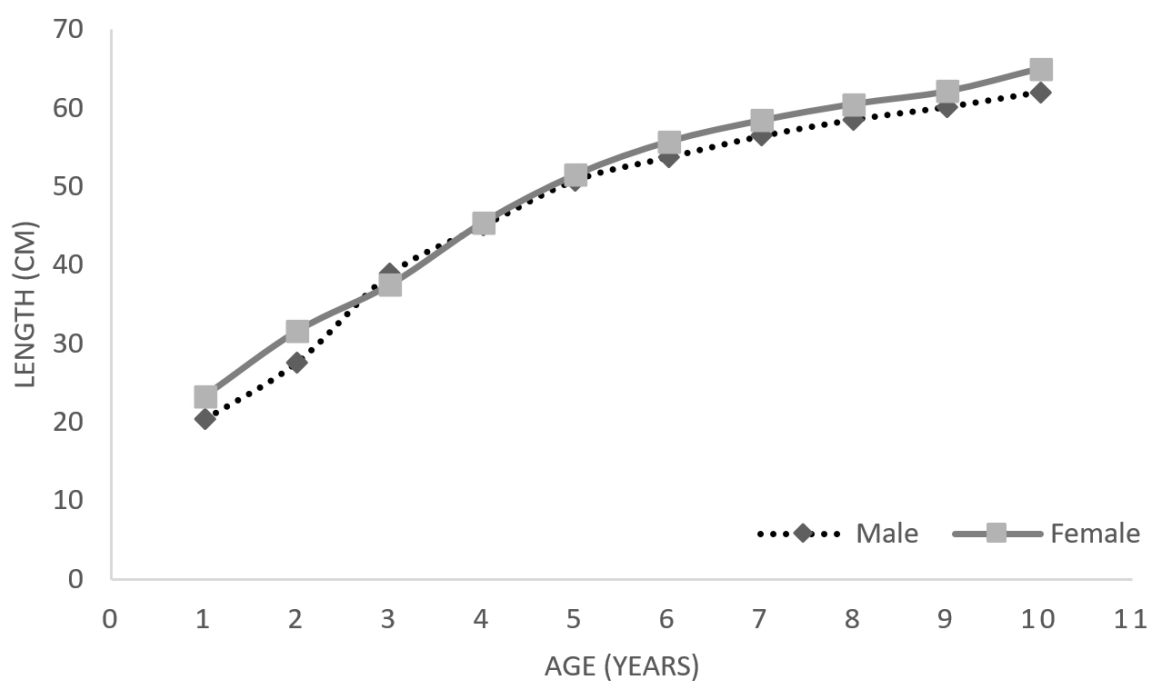

Fig 2. Differentiation by sexes of VBGF parameters of Lophius budegassa (continuous line for female and stippled line for males)

\section{DISCUSSION}

According to previous studies, results of the illicia reading methods as mean sizes were generally found to be smaller than length-frequency analyses. For instance, according to Carlucci et al. (2019), estimated mean length of age 2 for combined sexes was reported to be $22.2 \mathrm{~cm}$, and in the present study it was $22.4 \mathrm{~cm}$. However, according to Landa and Barcala (2017), results of length-frequency analyses (SLCA - ELEFAN - MPA - Bhattacharya) were reported to be $35.8 \mathrm{~cm}, 32.7 \mathrm{~cm}$ and $34.1 \mathrm{~cm}$, respectively. In this study, the biggest struggle arose from being unable to determine length ranges of age 0 and age 1 , and also lack of larger individuals of males.
So far, age determination methods of $L$. budegassa consisted of different methodologies such as used on illicium, otoliths and length-frequency analyses. In recent years and after several conducted workshops, the researchers focused on illicium reading, however, growth values are indicating that the growth rate of $L$. budegassa notably differs from mean lengths of the age classes. These differences in mean length at age observed between studies are probably caused by the differences in the method of observation (Landa et al., 2001). Abundance of all obtained fishes indicate inconsistency of ages based on mean length for male and female individuals (Table 3). 


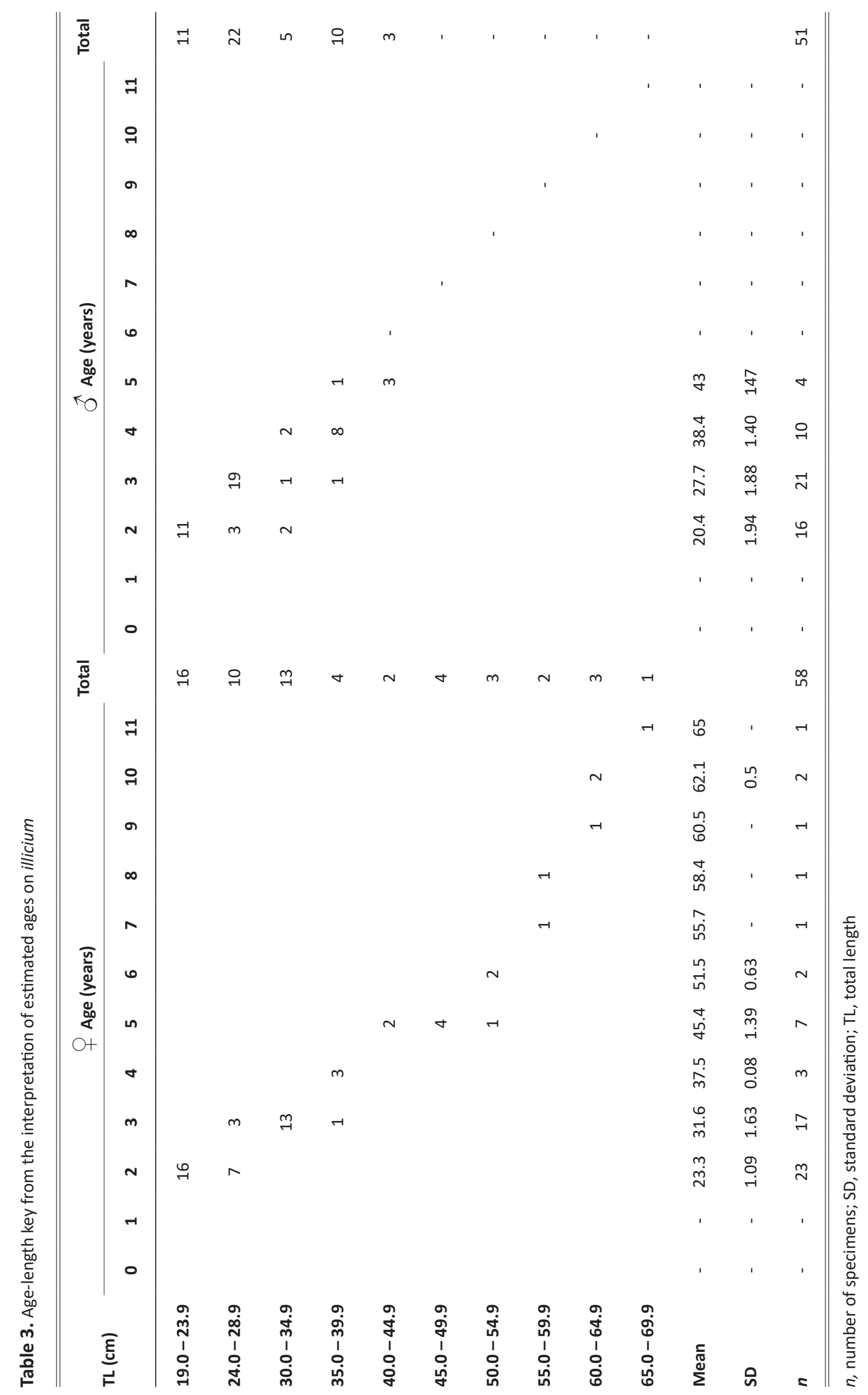




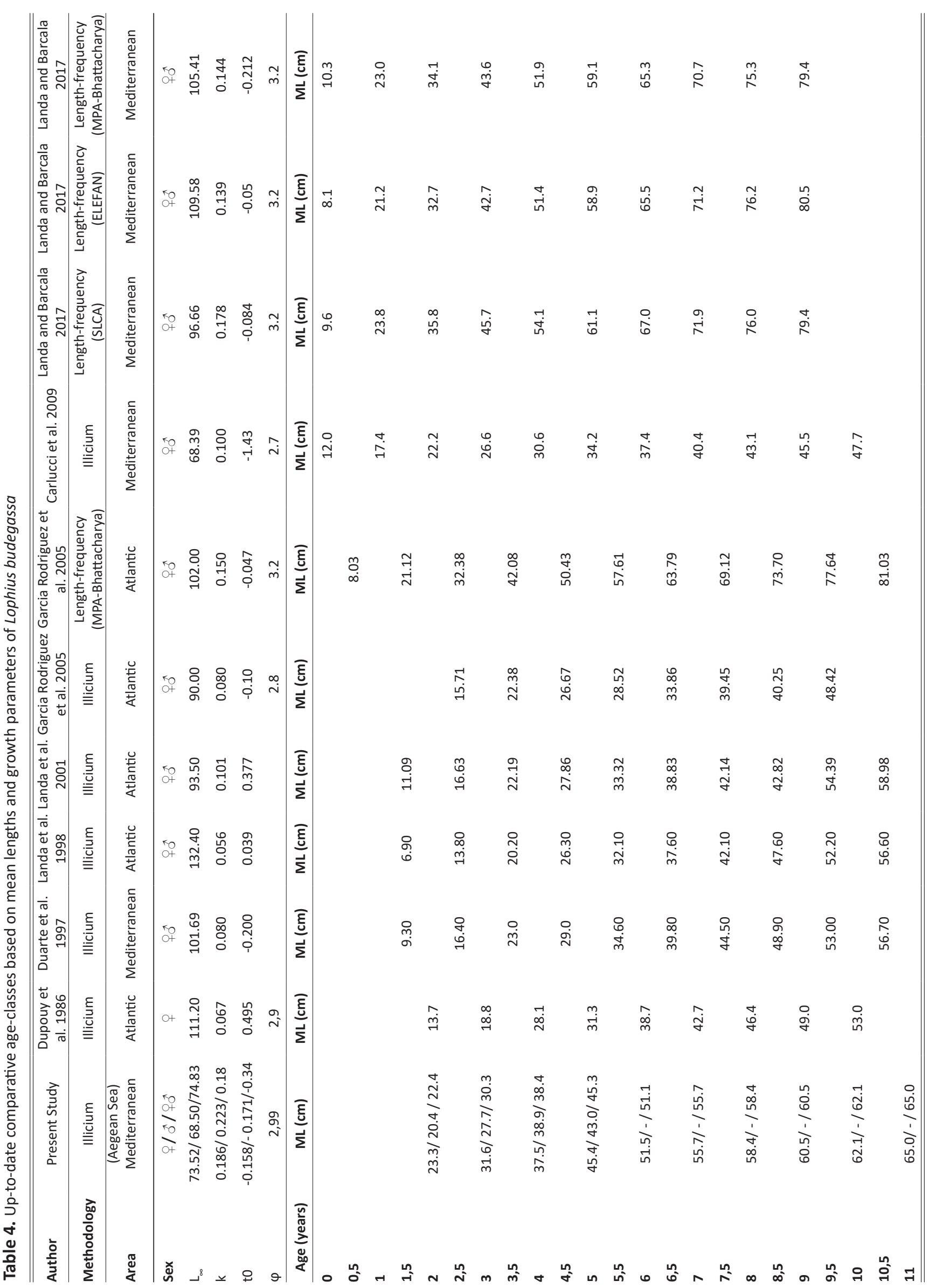


In previous illicium-based age studies that were made by Dupouy et al. (1986), designated age classes were found to be 2 to 10 years, by Duarte et al. (1997) they were found to be 1.5 to 10.5 years, by Garcia Rodriguez et al. (2005) they were found to be 2.5 to 9.5 years, by Carlucci et al. (2009) they were found to be 0 to 9.5 years, and finally in the present study within 2 to 11 years.

The size distribution of the population was found to be between $15.5-20 \mathrm{~cm}$ for female individuals, $15-18 \mathrm{~cm}$ for males and $15.5-16.5 \mathrm{~cm}$ for all individuals, $21 \%, 19 \%$ and $18 \%$, respectively. Based on these data, it is concluded that these fishes were exposed to severe prey pressure in the Central Aegean Sea or that larger individuals chose to inhabit deeper waters. Carlucci et al. (2009) reported that the average sizes of female individuals of $L$. budegassa are larger than male individuals. Our finding supports this statement and comparative values of lengths of genders are apparent to observe the differentiation of growth. Also, according to Laurenson et al. (2008), large individuals are present in deeper waters. In our research, the change between the maximum length of male and female individuals is noteworthy. The maximum total length of female individuals was found to be $65 \mathrm{~cm}$, while the maximum total length of male individuals was found to be $43 \mathrm{~cm}$. Similar results have been found in previous studies. Landa et al. (2001) reported that the maximum total length of female and male individuals were $89 \mathrm{~cm}$ and $67 \mathrm{~cm}$, and Garcia-Rodriguez et al. (2005) reported that the maximum total length of female was $114 \mathrm{~cm}$, and the maximum total length of male individuals was $93 \mathrm{~cm}$. The existence of different growth values is based on the longevity of female individuals and the difference in metabolism between the two sexes (Pauly, 1994; Landa et al., 2001), while the females reach a larger size and the males have a slower growth rate after a certain length. According to the biological characteristics of this species, male individuals grow more slowly than female individuals and therefore they remain smaller (Duarte et al., 2001). According to the comparative value of the growth performance index $(\varphi)$, in this study it is observed that there is no statistically significant difference between the growth coefficients obtained from previous studies (Table 4).

\section{CONCLUSIONS}

After all, this study could not reveal age and growth of the population of Lophius budegassa in the Central Aegean Sea because of the inability to obtain over-grown individuals during the study period. It has been suggested that there should be more workshops with relevant research about estimating the age of European anglerfish in order to eliminate the disagreements in age reading and to find the appropriate methodology.

\section{ACKNOWLEDGMENTS}

We would like to thank Dr. Sencer Akalın for his assistance. This study was supported by Ege University - Scientific Research Projects Coordination as 18-SUF-009 Scientific Research Project.

\section{DOB I RAST GRDOBINE ŽUTKE Lophius budegassa IZ CENTRALNOG EGEJSKOG MORA U TURSKOJ}

U svrhu utvrđivanja dobi i rasta, ukupno 558 primjeraka grdobine žutke Lophius budegassa (Spinola, 1807) je uzorkovano povlačnim ribarskim mrežama pri komercijalnom ribolovu u srednjem Egejskom moru u razdoblju od rujna 2017. do kolovoza 2018. Dob se određivala brojanjem prstena rasta na poprečnom presjeku illiciuma (modificirane prve dorzalne peraje). Očitavanjem illiciuma jedinke su kategorizirane u dobne skupine od II-XI. Vrijednosti totalne dužine i mase su se kretale između 12,0 - 65,0 cm, odnosno $24,5-4682,0$ g. Von Bertalanffy parametri rasta procijenjeni su za mužjake, ženke i kombinirani spol L. budegassa. Također, rezultati su uspoređeni s prethodnim istraživanjima.

Ključne riječi: grdobina žutka, Lophius budegassa, dob, rast, Srednjoegejsko more

\section{REFERENCES}

Anon, (1991): Report of the atelier franco-espagnol d'estimation de l'age des baudroies europeenes. Ifremer, 23.

Anon, (1997): Report of the Atelier International d'estimation de l'age des baudrois europeennes. Ifremer, 34.

Anon, (1999): Report of the 3rd International Ageing Workshop on European Anglerfish (Lophius piscatorius and Lophius budegassa). Ipimar, 106.

Carlucci, R., Capezzuto, F., Maiorano, P., Sion, L., D’Onghia, G. (2009): Distribution, population structure and dynamics of the black anglerfish (Lophius budegassa) (Spinola, 1987) in the Eastern Mediterranean Sea. Fisheries Research, 95, 1, 76-87.

Dardignac, J. (1988): Les pecheries du golfe de GascogneBilan des connaissances. Rapports Scientifiques Et Techniques De L'ifremer, 9, 111-130.

Duarte, R., Azevedo, M., Landa, J., Pereda, P. (2001): Reproduction of anglerfish (Lophius budegassa Spinola and Lophius piscatorius Linnaeus) from the Atlantic Iberian coast. Fisheries Research, 51, 2-3, 349-361.

Duarte, R., Azevedo, M., Pereda, P. (1997): Study on the growth of southern black and white monkfish stocks. ICES Journal of Marine Science, 54, 5, 866-874. 
Duarte, R., Landa, J., Quincoces, I., Dupouy, H., Bilbao, E., Dimeet, J., Marc al, A., McCormick, H., Chonchuir, G. (2002): Anglerfish Ageing Guide. In: Report of the $4^{\text {th }}$ international ageing workshop on European anglerfish, Ipimar, Lisbon, 11, 866-874.

Dupouy, H., Pajot, R., Kergoat, B. (1986): Etude De La Crolssance Des Baudroies, Lophius PIscatorius Et L. Budegassa, De L'atlantique Nord-Est Obtenue À Partır De L'illicium. Revue des travaux de l'Institut des pêches maritimes, 48, 3-4, 107-131.

Fishbase, (2018): Family details for Lophiidae. [cited 2018 August 4]. Available from: https://www.fishbase.de/ summary/FamilySummary.php?ID=190

Garcia-Rodriguez, M., Pereda, P., Landa, J., Estéban, A. (2005): On the biology of the anglerfish Lophius budegassa, Spinola, 1807 in the Spanish Mediterranean: a preliminary approach. Fisheries Research, 71, 2, 197208.

Landa, J., Barcala, E. (2017): Corroboration of Fast Growth Rate of Blackbellied Angler (Lophius budegassa) in Spanish Mediterranean. Fisheries and Aquaculture Journal, 8, 4, 1C-1C.

Landa, J., Duarte, R., Quincoces, I., Dupouy, H., Bilbao, E., Dimeet, J., Lucio, P., Marc al, A., McCormick, H., Ni Chonchuir, G. (2002): Report of the $4^{\text {th }}$ International Ageing Workshop on European Anglerfish. Ipimar, Lisbon.

Landa, J., Pereda, P., Duarte, R., Azevedo, M. (1998): Growth study of white and black anglerfish (Lophius piscatorius Linnaeus, 1758; Lophius budegassa Spinola 1807) based on annual sampling in the southern stock (ICES Divisions VIIIc and IXa). In: ICES Council Meeting papers, CM-1998/O, 21, 41.
Landa, J., Pereda, P., Duarte, R., Azevedo, M. (2001): Growth of anglerfish (Lophius piscatorius and $L$. budegassa) in Atlantic Iberian waters. Fisheries Research, 51, 2-3, 363-376.

Laurenson, C. H., Dobby, H., McLay, H. A. (2008): The Lophius budegassa component of monkfish catches in Scottish waters. Ices Journal of Marine Science, 65, 7, 1346-1349.

Maigret, J., Ly, B. (1986): Les Poissons de Mer de Mauritanie. Compiègne, France: science naturelle, 213.

Pauly, D. (1994): On the sex of fish and the gender of scientists. In: Essays in Fisheries Science, Series No. 14.

Sokal, R. R., Rohlf, F. J. (1969): Biometry. The principles and practice of statistics in biological research. San Francisco, WH Freeman.

Sparre, P., Ursin, E., Venema, S. C. (1989): Introduction to tropical fish stock assesment. Part 1- Manual. FAO Fisheries Technical Papers, 306, 1, 1-163.

Von Bertalanffy, L. (1938): A quantitative theory of organic growth (inquiries on growth laws II). Human Biology, 10, 2, 181-213.

Whitehead, P. J. P., Bauchot, M. L., Hureau, J. C., Nielsen, J., Tortonese, E. (1986): Lophiidae. pp. 1362-1363 In: Caruso, J. H. (eds). Fishes of the North-eastern Atlantic and the Mediterranean, Vol. 3. Paris, Unesco. 